\title{
The Contribution of Deposit Money Banks on the Growth of the Agricultural Sector in Nigeria
}

\author{
Ogar Anthony \\ Department of Banking \& Finance, University Of Calabar, Calabar. \\ Enya Emori Gabriel \\ Department of Banking \& Finance, University Of Calabar, Calabar. \\ Oka Felix Arikpo \\ Department of Banking \& Finance, University Of Calabar, Calabar.
}

\begin{abstract}
The objective of this study was to investigate the role of deposit money banks credit on the growth of the agricultural sector in Nigeria between the periods 1988 to 2011. An ex-post facto research design was used for the study. Three research objectives were formulated. Data were sourced principally from the secondary sources and was collected from the CBN Statistical Bulletin. The Data were analyzed using the ordinary least square multiple Regression Statistical Technique. Result from the analysis revealed that both deposit money banks loans and the agricultural credit guarantee scheme fund had a positive relationship with the output of the agricultural sector. It was however discovered that agricultural credit guarantee scheme fund's relationship was insignificant. It was finally revealed that deposit money bank lending rate had a negative and insignificant relationship with the output of the agricultural sector in Nigeria. Based on these findings, it was recommended that the loans and finances to the agricultural sector should be increased while the lending rate should be reduced. Also, the conditions to be fulfilled by farmers before accessing the agricultural credit guarantee scheme fund should be reviewed. Keywords: Deposit money bank; credit; loan and total agricultural output
\end{abstract}

\section{INTRODUCTION}

The need to increase food security, industrial development and our export base calls for a strong focus on agriculture since agriculture is a reliable source of industrial and food supply. Agriculture is the cultivation of land, rearing of animals for the purpose of production of food for man, feed for animals and raw materials for our industries (Anyanwu, Oaikhenan, Oyefusi \& Dimowo, 1997)). Agriculture has been identified as been responsible for key development in the rise of sedentary human civilization, whereby farming of domesticated species created food surpluses that nurtured the development of civilization (Ayegba \& Ikani, 2013). It is essential for the expansion of employment opportunities, reduction of poverty and improvement of income distribution, speeding up of industrialization and easing off on the pressure of balance of payments disequilibrium.

Nigerian agriculture is divided into subsistence agriculture and commercial agriculture. The subsistence agriculture is one that involves only the farmer and his family that is the farmer produce for himself and his family with very little or more to sell in the market. It involves only a little amount of money to practice. It does not invite any machinery to practice since the land is small and fragmented (Amechi, 2004). Commercial agriculture, on the other hand is where a 
farmer produces her crops and sells them in the market. It is carried out in large scale with large hectares of land and machines.

The role of credit in agriculture cannot be over emphasized. Credit is a financial resource obtained at a certain period of time with the obligation to repay at a subsequent period in accordance with the terms and conditions of the credit obtained (Ijaija \& Abduraheem, 2000). Credits could come from financially able bodies like banks, government or individuals (see, Olaitan, 2006 and Cornelius, Arikpo \& Ogar, 2015).

Agricultural credit on the other hand, is the loan extended to farmers for production, storage, processing and marketing of farm produce. This credit can be short, medium or long term depending on its duration. Agricultural credit is sometimes referred to as farm credit. Farm credit plays a crucial role in agricultural development as it enables farmers reap economies of scale, venture into new fields of production, employ new technologies and empower them to provide utilities for a widening market (Ayegba \& Ikani, 2013). Agricultural credit can have a secondary spillover effect on nonfarm household through input, labour and output linkages. Nzotta (1999) held that agricultural credit reactivates, expands or modernizes all types of agricultural enterprises which are considered economically feasible and desirable to the achievement of stated economic goals of self-sufficiency in agricultural production. While Qureshi, Khan \& Shan (1992) reported that such credit removes financial constraints faced by farmers' as it provides incentives to adopt new technologies that would otherwise be more slowly accepted. Thus the availability of credit enables farmers to switch quickly to new technologies which enable the achievement of rapid productivity and growth.

Since suppliers of credit (deposit money banks) are in business for profit and will only lend to credit worthy sectors and knowing the positive role played by agricultural credit on food production, consumption and agricultural inputs, the Federal Government of Nigeria decided to established the agricultural credit guarantee Scheme (ACGS) with capital base of three billion naira (N3 billion) to guarantee credit extension to Nigerian farmers. This study is designed to assess the role of deposit money banks credit on the growth of the agricultural sector in Nigeria.

The Nigerian agricultural sector is characterized by many problems; noticeable among them is inadequate finance. The difficulties in accessing loans from deposit money banks has limited the ability of the sector to expand it production, used modern technologies, provide employment opportunities to the teeming population and contribute to the growth of the Nigerian economy. To solve these problems, many policy dimensions have been evolved meant to increase the funding to the agricultural sector including the requirement of banks to play pivotal roles in providing cheap credit to the sector's operators.

The truth remains however that deposit money banks have not fully comply with this policy requirement as there are still rumors of the unwillingness of the banks to grant credit to the sector's operators. Furthermore, where credits are granted, the interest charges are often too high. Other problems associated with the access to deposit money banks' credit by the agricultural sector include: excessive paper work, requirement for collateral securities and the fear of default in the payment of the principal and interest by banks.

The aforementioned problems therefore call for an empirical investigation of the role of deposit money banks on the performance of the agricultural sector in Nigeria. Hence, the broad objective of the study is to investigate the extent to which deposit money banks credit 
had supported agricultural output in Nigeria. However, the specific objectives of the study are as follows.

I. To determine the relationship between deposit money banks credit and agricultural output in Nigeria.

II. To determine the relationship between deposit money banks leading rate and the output of the agricultural sector in Nigeria.

III. To assess the relationship between the agricultural guarantee scheme fund and the output of the agricultural sector in Nigeria.

In order to achieve the above objectives, the paper is organized into five different sections. Section one is the introduction. It captures important issues relating to the role of deposit money banks on the performance of agricultural sector in Nigeria. Section two covers the theory behind deposit money banks credit to the agricultural sectors and relevant literature review. Section three handles the research methodology. Section four focuses on data presentation, analysis and discussion of findings relating to this study. Section five is on conclusion and then recommendations emerging from the study.

\section{Commercial Loan Theory}

THEORETICAL FRAMEWORK AND LITERATURE REVIEW

The theory upon which this study is built is the commercial loan theory. The commercial loan theory also referred to as the Real Bills Doctrine states that a commercial bank should advance only short term self liquidating productive loans to business firms, self liquidating loans are those loans which are meant to finance the production and movement of goods though the successive stages of production; storage, transportation and distributions. When such goods are ultimately sold, the loans are considered to liquidate themselves automatically, (Jhingan, 2009).

Under this theory, the ideal assets of commercial banks should consist of short-term business loans made to business firms for the management of their working capital. When a bank finances the working capital of a firm, it expects funds for repayment to come from the management of working capital itself (Mbat, 2001).

The theory posits believe that when commercial banks make only short term liquidating productive loans, the central bank, in turn, should lend to the banks only on the security of such short term loans. This principle would ensure the proper degree of liquidity for each bank and the proper money supply for the whole economy. The Central Bank is expected to increase or diminish bank reserves by re-discounting approved loans when business expand and the need to trade increase, banks are able to acquire additional reserve by re-discounting bills with the Central Bank when business fall and the need for trade declines, the volume of rediscounting of bills would fall, the supply of bank reserves and the amount of bank credit and money would also contract.

Considering this theory as it relates to the agricultural sector, Commercial Banks are expected to grant short term self liquidating loans to farmers for financing their working capital needs. There loans are expected to be used basically for farming activities and the loan repayment should come from the farm proceed.

\section{LITERATURE REVIEW}

Finance has a derive demand and is one major input required for all productive activities in general and agricultural development in particular. It represents the power to purchase all other inputs and expand organizational productivity. It is therefore one of the major 
determinants of the level of development in agriculture. Mbat (2001) defined finance as a system which incorporates the circulation of money, granting of money credit, investments as well as provision of banking facilities. One aspect of finance therefore is the provision of credit facilities to the deficit economic units by deposit money banks.

Essang \& Olayide, (1974) held that deposit money banks are monetary institutions owned by either the government or private business men for the purpose of profit. In pursuit of the profit, the bank undertakes a number of functions. One of these functions is the acceptance of deposits from the public, these deposit are in turn given out as credit to traders, industries, farmers, etc, which lead to more production and employment (Stephen \& Osagai, 1985, Ekezie, 1997; Ijaya \& Abduraheem, 2000 Ugwu, 2010).

Credit has been defined by Okereke (2003) as the fund-base and non fund-base activities of backs that exposes them to risk of varying degree. This definition is widely accepted since it presents the basic element of credit which is risk. Since the payment of both the principal amount and the interest is done in a future date, it follows that the risk of default could be inherent. Supporting the Okereke, is the NDIC prudential guidelines of 1990 which held that credit comprise of an aggregates of all loans, advances, overdrafts, commercial papers, bankers acceptances, bills discounted, leases and guarantees (NDIC, 1990).

Agricultural credit is the credit granted to farm and ranch operators to assist in planting and harvesting of crops to support the feeding and care of livestock (Mufbau, 2003). Credit to the agricultural sector could take the form of overdrafts, short term loans, medium term or long term loans depending on the purpose and gestation period of the project (Ugwu, 2013). Such credits granted to farmers to purchase inputs are paid directly to the suppliers who must furnish the bank with evidence of delivery. This is done to avert diversion of funds, which is common with Nigerian farmers (Adekanye, 1986; Nzotta, 1999).

Discussing the importance of credit to the agricultural sector, Nzotta, (1999) argued that it reactivates, expands and modernizes all types of agricultural enterprise which are considered economically feasible and desirable to the achievement of stated economic goals of self sufficiency in agricultural production while Qureshi, Khan \& Shan (1992) explained that such credit removes financial constraints faced by farmers, as it provides incentives to adopt new technologies that would have otherwise been more slowly accepted. Thus, access credit enables farmers to switch quickly to new technologies which enhance the achievement of a rapid productivity and growth.

According to Ijere (1996) credit can be considered from its ability to energize and motivate other factors of production. For example, it can make the latent potential or under used capacities functional. He further said that credits acts as catalyst that activate the engine of growth enabling it to mobilize its inherent potentials and attain speedy results. It follows, therefore, that the greater the "influx of capital, the more the propensity of the economy to grow. As summarized by Fosu (1992), Amin (1996) and Ogen (2007) credit constitute the power or key to unlock latent talents, abilities, vision and opportunities which in turn act as the engine of the economic development. Contributing to this argument about Wells (1920) confirms that credit contributes to economic development by enhancing production and growth. It thus enhances higher income and better quality of life for people.

Several studies have been carried out on deposit money banks and the finance of agriculture in Nigeria. According to Ollor \& Okoye (1983), the availability of credit to local farmers poses a 
serious problem. This is because of the rate of increase of default cases among small scale farmers. Commercial Banks in Nigeria were unwilling to grant credits to small scale farmers because of the high rate of default associated mostly with loan repayment, and lack of collateral security often demanded by banks during load agreement (kehinde, 2012). It is in this light that the government has always maintained that deposit money banks should not neglect agricultural and allied activities since they are the chief agent of mobilization of savings (Ugwu, 2010).

Irrespective of the unwillingness of deposit money banks to grant credit to agriculture in general and small scale farmers in particular, studies carried out by Anyanwu, Oaikhenan, Oyefusi \& Dimowo (1997), Garba (2000) and Ijere (1975) highlighted the need for increasing the volume of loan resources available to the credit institutions so as to enhance lending to the individuals borrows. However, Ogunfowora (1972) attributed most of the short comings of institutional credits in Nigeria to such factors as ineffective supervision or monitoring, insufficient funds, political interference, cumbersome and time consuming loan processing and absence of financial projections.

The importance of effective evaluation of borrowers before granting credit facilities is to ensure that all condition attached to the approval of credits facilities are complied with. Evaluating the borrower enables the lending institution identifying emergent problems before they get out of control Mbat (2001). It is also important to conduct a follow up supervision and monitoring of projects on which the acquired facilities were invested. This could enable financial institutions to identify problems associated with such projects before they get out of hand. Problems detected earlier through warning signals could be easily solved to avoid total loss of the project (Ugwu, 2010). Agricultural facilities granted are closely monitored; this is occasioned by the nature of the industry, especially the production aspect that is highly risky because of its precarious nature (Olagunju \& Adeyomo, 2007). Agricultural facilities are also known to be specific purpose oriented as a result of follow-up facilities, the indications of a possibility of default usually referred to as "danger signs" are easily detected, a current finding in the view on bank credit management (Ugwu, 2010).

\section{RESEARCH METHODOLOGY}

The design that will be used for this study is the ex-post facto research design. This design has been adjudge appropriate as the events under study have already taken place. The researchers have no control over the variables under study simply because they have already been manipulated before they were applied in this study. Unlike the experimental design, statistical techniques will be applied in the treatment of the events under study.

Both the study literature review and hypotheses testing were based on the secondary source of data. They were sourced from the published works of various scholars in test books, articles, journals and government publications like the CBN statistical Bulletin.

Time series data were collected for the period between 1988 and 2011 on Total Output of Agricultural Products (TOAP), Deposit Money Bank Loans to the agricultural sector (DMBL), and Deposit Money Bank Lending Rate (DMBLR). The desk survey method was used to extract data on the variables from the publications bearing in mind the study objectives and hypotheses.

Data collected were presented in tables. The ordinary least squares multiple regression analytical technique and interpretation was used. This technique was justified as it is the best linear unbiased estimate (BLUE) of relationship. 


\section{MODEL SPECIFICATION}

The specified model for this study was the ordinary least square multiple regression model. In this model the index to be used to measure the dependent variable will be the Total Output of Agricultural Products (TOAF) while Deposit Money Bank Loans to the agricultural sector (DMBL), Deposit Money Bank Lending Rate (DMBLR) and Agricultural credit Guarantee Scheme Fund (ACGSF) were used to measure the independent variables. The model was as stated below

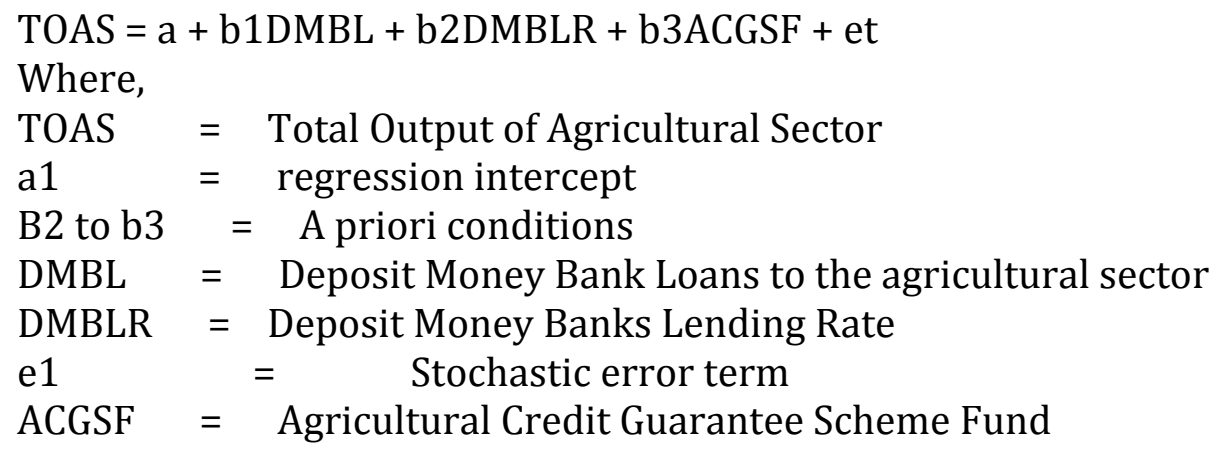

Data Presentation, Analysis and Discussion of Findings

DATA PRESENTATION

Presented in table 1 below is the empirical data on the contribution of deposit money banks on the growth of the agricultural sector in Nigeria

TABLE 1

\begin{tabular}{|l|l|l|l|l|}
\hline YEAR & TOAP & DMBL & DMBLR & ACGSF \\
\hline 1988 & 57924.38 & 3066.7 & 16.5 & 126346.9 \\
\hline 1989 & 69713 & 3470.5 & 26.8 & 134066.7 \\
\hline 1990 & 84344.61 & 4221.4 & 25.5 & 103395.2 \\
\hline 1991 & 97464.06 & 5012.7 & 20.01 & 80859.6 \\
\hline 1992 & 145225.3 & 6978.9 & 29.8 & 93391.8 \\
\hline 1993 & 231832.7 & 10753 & 18.32 & 81273.8 \\
\hline 1994 & 349244.9 & 17757.7 & 21 & 106901 \\
\hline 1995 & 619806.8 & 25278.7 & 20.18 & 166645.1 \\
\hline 1996 & 841457.1 & 33264.1 & 19.74 & 227664.5 \\
\hline 1997 & 953549.4 & 27939.3 & 13.54 & 242028.3 \\
\hline 1998 & 1057584 & 27180.7 & 18.29 & 220288.5 \\
\hline 1999 & 1127693 & 31045.7 & 21.32 & 241839 \\
\hline 2000 & 119290 & 41028.9 & 17.98 & 361449 \\
\hline 2001 & 1594896 & 55846.1 & 18.29 & 728545.4 \\
\hline 2002 & 3357063 & 59849.7 & 24.85 & 1050982 \\
\hline 2003 & 3624579 & 62102.8 & 20.71 & 115105 \\
\hline 2004 & 3903759 & 67738.6 & 19.18 & 2083745 \\
\hline 2005 & 4773198 & 48561.5 & 17.97 & 9493855 \\
\hline 2006 & 5940237 & 49393.4 & 17.26 & 4262430 \\
\hline 2007 & 6757868 & 149578.9 & 16.94 & 4425462 \\
\hline 2008 & 7981397 & 106353.8 & 15.14 & 6497959 \\
\hline 2009 & 9186306 & 449475.1 & 18.99 & 8328566 \\
\hline 2010 & 10310656 & 591982.7 & 17.59 & 6567357 \\
\hline 2011 & 11590120 & 791291.7 & 16.03 & 10189604 \\
\hline & & & & \\
\hline
\end{tabular}

Source: CBN Statistical Bulletin, vol. 22, 2011. 


\section{DATA ANALYSIS}

For the purpose of analysis, the econometric model earlier specified will be restated; thus:

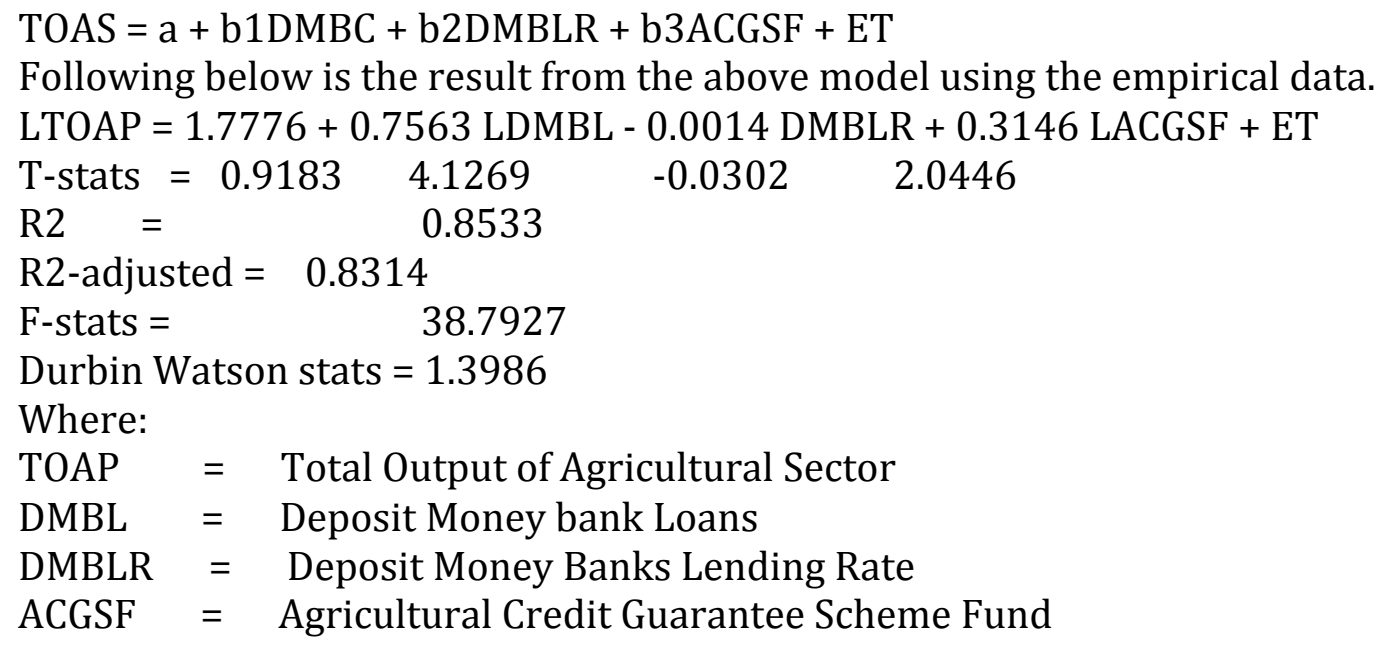

From the empirical result, the a priori expectation about the size of deposit money banks loans (DMBL) and Agricultural Credit Guarantee Scheme Fund (ACGSF) conformed to economic theory. The parameters entered the model with positive signs implying that both deposit money bank loans (DMBL) and Agricultural Credit Guarantee Scheme Fund (ACGSF) have positive impact on the Total Output in the Agricultural Sector. Stated differently, an increase by one percents $(1 \%)$ in deposit money bank loans to the agricultural sector and agricultural credit guarantee scheme fund resulted in about $75.63 \%$ and $31.46 \%$ increases in the total output of agricultural sector respectively.

Deposit Money banks Lending Rates do not conform to economic theory. The parameters entered the model with a negative sign. This implies that an increase by one percent (1\%) in deposit money bank lending rate resulted in a $0.14 \%$ decrease in total agricultural productivity in Nigeria.

The goodness of fit of the model as indicated by the R2 -adjusted value 0.8314 or $83.14 \%$ showed that the model fits the data well, the total variation in the observed behavior of the total agricultural productivity as a measure of the growth of the agricultural sector is jointly explained by the variation in deposit money bank loans (DMBL), Deposit Money Bank Lending Rate (DMBLR) and Agricultural Credit Guarantee Scheme Fund (ACGSF) up to 83.14\%. The remaining $16.86 \%$ is accounted for the stochastic error data.

The overall significance of the model was also tested using the ANOVA or F-statistics. Here, the high significance of the F-statistics value of 38.7927 did not occurs by chance, it actually confirmed that the model fitted the data well.

The individual statistical significance of the parameters of the respective independent variables was also tested. Both deposit money bank lending rate (DMBLR) and Agriculture Credit Guarantee Scheme Fund (ACGSF) were statistically insignificant for measuring variations in total agricultural productivity. Here, the calculated t-statistic value of 0.03202 and 2.0446 for deposit money bank lending rate and agricultural credit guarantee scheme fund respectively were found to be less than the table t-statistics value of 2.064 at $5 \%$ level of significance.

Furthermore, the deposit money bank loans was found to be a statistically significant for measuring variations in the total output of agriculture in Nigeria as its calculated t-statistics 
value of 4.1269 was found to be greater than its table t-statistics value of 2.064 at $5 \%$ significance level.

The test for the existence of auto-correlation was performed using Durbin-Watson statistic. The test for the existence of serial autocorrelation showed that there is the presence of autocorrelation problem in the model as the computed durbin Watson did not fall within the du and 4-du region

\section{DISCUSSION OF FINDINGS}

The result of the data analysis revealed first that there exist a positive and significant relationship between deposit money bank loans and the total output of the agricultural sector in Nigeria. These findings showed that as deposit money bank loans to the agricultural sectors increases, agricultural productivity also increases significantly. This finding is in agreement with the findings of Wells (1970), who in his findings posited that deposit money bank loans enhances production and productivity of the agricultural sector and brings a better quality of life.

It was also unveiled from the analysis that there exist a negative and an insignificant relationship between deposit money banks lending rate and the output of the agricultural sector in Nigeria. This finding could be attributed to the high lending rates charged by the deposit money banks and the unwillingness on the part of the regulatory authorities to reduce or reform the lending rates. This finding is in agreement with the findings of Ogunfowora (1972) who posited that commercial banks lending to the preferred sector at high rates deters the sectors operations from obtaining loans for the expansion of their operations.

Finally, the findings from the analysis revealed a positive but insignificant relationship between the agricultural credit guarantee scheme fund and the output of the agricultural sector in Nigeria. This finding could be attributed to the high conditions placed by the regulatory authorities as the prerequisites of benefiting from the scheme and the low turnout of farmers in patronizing the scheme. These findings is in agreement with Akinleye (2005), who posited that the contribution of agricultural credit guarantee scheme fund to the output of the agricultural sector is limited by factors such as lack of awareness, personal guarantee problems, increase incidence of loan default, etc.

\section{CONCLUSION AND RECOMMENDATION}

From the findings of this study, it is obvious that both deposit money bank loans and agricultural credit guarantee scheme fund have positive relationships with the growth of the agricultural sector in Nigeria. However, the agricultural credit guarantee scheme fund was not statistically significant for measuring variations in the growth of the agricultural sector in Nigeria. It was also revealed that deposit money banks lending rate has an inverse and insignificant relationship with the growth of the agricultural sector in Nigeria.

Conclusively, the deposit money banks in Nigeria play a veritable role in promoting agricultural productive and growth through the provision of funds (in form of loans and grants) to the sector.

Based on the findings of this study, the following recommendations were made Effort should be made by the government and private individuals to encourage or increase investment in the agricultural sector. 
The lending rate on loans to the agricultural sector should be reviewed and fixed at a rate that would encourage farmers to acquire loans from deposit money banks.

The stringent conditions and pre-requisite required to be met by farmers to participate on the agricultural credit guarantee scheme fund should be reviewed and made accessible to farmers. Government should ensure that bank claims as a result of default and borrowers interest draw backs are paid without delay. This will not only motivate both participating banks and formers in the scheme but will also attract others who are skeptical about it. The end result is the nation reaping the dividend of adequate credit put into our agricultural sector and this is seen in increased productivity which is a sine qua non in agricultural development.

\section{References}

Adekanye, F. (1986). Practice of banking. London: Collins Publishing Company.

Amechi, N.F. (2004). Model agricultural science. Oko: Federal Polytechnic press.

Amin, A. A. (1996). The effect of exchange rate policy on Cameroon's agricultural competitiveness. Nairobi: ARC Publishers.

Anyanwu, Oaikhenan, Oyefusi \& Dimowo (1997). The structure of the Nigerian economy (1960-1997). Joanee Educational Publishing Ltd.

Ayegba, O. \& Ikani, D. I. (2013). An impact assessment of agricultural credit on rural farmers in Nigeria. Research Journal of finance and Accounting. 4 (18).

Cornelius, M. O. Arikpo, O. F. Anthony, O. (2015). The role of deposit money banks on the growth of SMEs in Yakurr Local Government Area, Cross River State, Nigeria. Journal of Social Science Research. 6 (2).

Ekzie, E.S. (1997). The elements of banking money financial institutions and markets. Onitsha: Africana-fep Republishes.

Essang, S. \& Olajide, S. (1974). Intermediate economic analysis. Ibadan: Aromolara Publishing Company Limited. FOSU, K.F. (1992). The Real exchange rate and Ghanas agricultural export. Nairobi: ARC Publishers.

Garba, P.K. (2000). An analysis of the implementation and stability of Nigerian agricultural policies, 1970-1993. AERC Research Paper 101, Nairobi: African Economic Research Consortium.

Ijaiya, G.T. \& Abdulraheem, A. (2000). Commercial Banks Credits to the Agricultural Sector and Poverty Reduction in Nigeria. A Calibration Analysis. Nigeria Journal of Agricbiz and Rural Development. 40(12).

Ijere, M.O. (1975). The problems and prospects in the administration of Agricultural Credit in East Central State and the Development of a New Programme. Enugu.

Ijere, M.O. (1986). New perspectives in Financing Nigeria Agriculture. Benin: Dimension Publishers.

Jhingan, M. L. (2004). Money banking, International Trade and Public Finance. India: Vrinda Publications Ltd.

Kehinde, A. A. (2012). Agricultural financing in Nigeria: an assessment of the Agricultural Credit Guarantee Scheme Fund (ACGSF) for food security in Nigeria (1978-2006). Journal of Economics. 3(1): 39-48.

Mbat, D. 0. (2001). financial management Uyo: Dome S. Associates Publishers.

Muftau, A.I. (2003). Commercial bank credit to the agricultural sector and the Nigerian economy. An analysis of the future trend. A Journal of Department of Business Administration. 28 (32).

Nigeria Deposit Insurance Corporation (1990). “Prudential Regulations and Guidelines for Banks, Lagos.

Nzotta, S.M. (1999). Money banking and finance theory and practice. Lagos: Intercontinental Publishing.

Ogen, O. (2007) the Agricultural Sector and Nigeria's Development: Comparative Perspectives from the Brazilian Agro-Industrial Economy, 1960-1995.

Ogunfowora, O., Essang, S. M. \& Olayide, S. O. (1972). Capital and credit in Nigerian agricultural development.

Nigerian rural development study paper No. 6, University of Ibadan, Ibadan, Nigeria. 
Anthony. O., Gabriel. E.E., \& Arikpo. O.F. (2015). The Contribution of Deposit Money Banks on the Growth of the Agricultural Sector in Nigera. Archive Research Journal, 3(2), 33-42.

Okereke, E. J. (2003). Banking in Nigeria: practice and management. Owerri: Jeso International Publishers.

Olagunju, F.I \& Adeyomo, R (2007) 'Agricultural Credit and Production Efficiency of Small Scale Farmers in SouthEastern Nigeria’ Agricultural Journal, 2(3) 426-433.

Olaitan, M.A. (2006). "Finance for Small and Medium Enterprises: Nigeria's Agricultural Credit Guarantee Scheme Fund". Journal of International Farm Management 3(2): 1-9.

Ollor, W. G. \& Okoye, E. 0. (1983). "An appraisal of the agricultural credit performance of Nigerian commercial banks, 1970-1980". Agricultural Administration Volume 13 (3): 137-152

Qureshi, Khan, S. Akhtar, H. \& Shan (1992), 'A critical review of rural credit policy in Pakistan. The Pakistan Development Review 31(4), 781 - 801.

Stephen, N.A. \& Osagie, E. (1985) A textbook on economics for West African studies. Ibadan. University Press.

Ugwu, C. M. (2010). Commercial bank credit and agricultural output in Nigeria (1982-2007). Enugu: Caritas University, Amorji Nike, Emene.

Wells, J. C. Carl, K. \& Eicher, L. (Eds.) (1970). Nigerian Development Plan in Growth and Development of the Nigerian Economy. USA: Michigam State University Press. 